\title{
Regulation of de novo Fatty Acid Biosynthesis in the n-Alkane-utilizing Yeast, Candida 107
}

\author{
By C. O. GILL AND C. RATLEDGE \\ Department of Biochemistry, The University of Hull, \\ Kingston upon Hull, $\mathrm{HU} 6{ }_{7} \mathrm{RX}$
}

(Received 25 April 1973)

\begin{abstract}
SUMMARY
Growth of Candida 107 on $n$-alkanes $\left(\mathrm{C}_{10}, \mathrm{C}_{16}\right.$ or a mixture) completely repressed formation of acetyl-CoA carboxylase and partially repressed the fatty acid synthetase complex. As all fatty acids must then be derived directly from the substrate no matter what its chain length, the yeast must be able to elongate even-chain acids $\left(C_{10}\right.$ to $\left.C_{14}\right)$ and modify, by unknown reactions, odd-chain acids to give even-chain acids. Short-term control of fatty acid biosynthesis appears to be by long-chain $\left(\mathrm{C}_{16}\right.$ or $\left.\mathrm{C}_{18}\right)$ fatty acyl-CoA esters feedback-inhibiting the activities of both acetylCoA carboxylase and fatty acid synthetase. $n$-Alkanes, $n$-alcohol, free fatty acids or $\mathrm{C}_{12}$ and $\mathrm{C}_{14}$ acyl-CoA esters, had little or no effects on these enzymes. Extracts from $n$-alkane-grown yeast inhibited the carboxylase in extracts from glucose-grown yeast, the pattern of inhibition being similar to that observed with hexadecyl-CoA.
\end{abstract}

\section{INTRODUCTION}

De novo fatty acid biosynthesis in yeast is catalysed by two soluble enzyme systems: acetyl-CoA carboxylase (EC. 6.4.I.2), equation I, and the multienzyme complex known as the fatty acid synthetase (Sumper \& Lynen, I972), equation 2

$$
\begin{aligned}
& \text { Acetyl-CoA }+\mathrm{HCO}_{3}{ }^{-}+\mathrm{ATP} \longrightarrow \text { malonyl-CoA }+\mathrm{ADP}+\mathrm{P}_{\mathrm{i}} \\
& \begin{array}{c}
\text { Acetyl-CoA }+7 \mathrm{Malonyl}-\mathrm{CoA}+\mathrm{I} 4 \mathrm{NADPH}+\mathrm{I}_{4} \mathrm{H}^{+} \longrightarrow \\
\text { hexadecyl-CoA }+7 \mathrm{CoA}+7 \mathrm{CO}_{2}+\mathrm{I}_{4} \mathrm{NADP}+6 \mathrm{H}_{2} \mathrm{O}
\end{array}
\end{aligned}
$$

Acetyl-CoA carboxylase is subject to allosteric regulation; it is activated by citrate and $\mathrm{Mg}^{2+}$ and inhibited by long-chain acyl-CoA thioesters in liver or adipose tissues (Vagelos, I97I ; Guynn, Veloso \& Veech, 1972) and in crude extracts of Saccharomyces cerevisiae (White \& Klein, 1965, 1966; Rasmussen \& Klein, 1968), though Matsuhashi (1969) has reported that the yeast enzyme is not so affected. This enzyme is repressed in Lactobacillus plantarum when grown in the presence of unsaturated fatty acids (Henderson \& McNeil, I966, I967; Birnbaum, I970; Weeks \& Wakil, I970) and partially repressed in starved rats (Majerus \& Kilburn, 1969) when lipolysis is presumably stimulated, but there have been no reports of its repression in yeasts (Hunter \& Rose, I97I).

The fatty acid synthetase complex in animals is stimulated by certain hexose phosphates (Wakil, Goldman, Williamson \& Toomey, 1966) and is inhibited by hexadecyl-CoA (Tubbs \& Garland, 1964; Dorsey \& Porter, 1968) which also inhibits the yeast enzyme (Lust \& Lynen, I968). Partial repression of the enzyme complex occurs in starved animals (Butterworth et al. 1966; Dahlen, Kennan \& Porter, I968; Burton, Collins, Kennan \& Porter, I969). Changes in the level of the related enzyme system have been reported in Lactobacillus plantarum (Birnbaum, 1970; Weeks \& Wakil, 1970) but not in yeasts. 
Addition of fatty acids, as such, to the medium can inhibit yeast growth (Bell, 1971, 1973; Gill \& Ratledge, I972) although small amounts can be used by Saccharomyces cerevisiae (Suomalainen \& Keränen, I968). A more suitable system for the study of control of de novo synthesis of fatty acids could therefore be to use alkane-utilizing micro-organisms. In these organisms, fatty acids are directly derived from alkanes (Davis, I964; Mizuno et al. 1966; see also Ratledge, 1970) without inhibition of growth. These fatty acids, in yeasts, may then be metabolized in one or more of three ways depending upon their chain length: (i) from $\mathrm{C}_{\mathbf{1 3}}$ to $C_{18}$ direct incorporation into lipids can occur; (ii) from $C_{9}$ to $C_{15}$ (and maybe higher) elongation of the chain is indicated to occur; and (iii) degradation to acetate occurs to some extent with all alkanes (Trust \& Millis, I970; Chenouda \& Jwanny, I972; Hornei, Köhler \& Weide, 1972; Thorpe \& Ratledge, I972; Hug \& Fiechter, 1973). In Candida 107, which can oxidize $n$-alkanes to fatty acids even when growing on glucose (Ratledge, I968; Gill \& Ratledge, 1973 $a$ ), one might therefore expect the system for de novo fatty acid synthesis to be regulated by repression of enzyme synthesis or feedback inhibition or both. We have now investigated such regulation; a preliminary communication of part of this work has already been made (Gill \& Ratledge, $1973 b$ ).

\section{METHODS}

Growth of the organism. Candida 107 was grown in shake-culture on a glucose + yeast extract + salts medium (Gill \& Ratledge, I972); after I $8 \mathrm{~h}$ all glucose had been consumed. To starve the yeast, incubation was continued for a further $24 \mathrm{~h}$. To adapt the yeast to complete alkane utilization, $20 \mathrm{ml}$ of the appropriate sterile alkane was added to each litre of culture after glucose exhaustion and then incubation continued for a further $24 \mathrm{~h}$. Alternatively, the yeast was grown in continuous culture at a dilution rate of $0 . \mathrm{I} \mathrm{h}^{-1}$ on $5 \%(\mathrm{v} / \mathrm{v})$ $n$-alkanes $\left(\mathrm{C}_{13}\right.$ to $\mathrm{C}_{16}$ fraction) in a $10-1$ fermenter (3-1 working vol.). The basal salts and vitamins of the medium were as described by Ratledge (I968) except that $\left(\mathrm{NH}_{4}\right)_{2} \mathrm{SO}_{4}$ was at $2.5 \mathrm{~g} / \mathrm{l}$ and Span 8I was added to $0 . \mathrm{I} \%(\mathrm{v} / \mathrm{v})$.

Preparation of cell-free extracts and assay of enzymes. Candida 107 was harvested by centrifuging for $5 \mathrm{~min}$ at $6000 \mathrm{~g}$, washed twice with $\mathrm{O}^{\circ} \mathrm{I} \mathrm{M}$-phosphate buffer, $\mathrm{pH} 7{ }^{\circ} \mathrm{O}$, and then, as a slurry in fresh buffer, disrupted by passage through a French press. The material was centrifuged for $15 \mathrm{~min}$ at $10000 \mathrm{~g}$ to remove whole yeast and debris and the supernatant solution re-centrifuged at $15000 \mathrm{~g}$ for $30 \mathrm{~min}$ to remove mitochondria. The final supernatant was filtered with suction through Whatman fibre-glass paper (grade A) to remove solidified fat. The protein concentration, determined by the method of Lowry, Rosebrough, Farr \& Randall (I95I), was adjusted for all cell-free extracts to $\mathrm{IO} \mathrm{mg} / \mathrm{ml}$ with $0 \cdot \mathrm{I} \mathrm{M}$-phosphate buffer. As the effect of some inhibitors, principally long-chain acyl-CoA thioesters, can be reversed by their binding to protein (Numa, Bortz \& Lynen, I965; Marquis, Francesconi \& Villee, 1968), a constant protein concentration was maintained to validate comparisons of inhibitory effects between different enzyme preparations.

Acetyl-CoA carboxylase (acetyl-CoA:carbon dioxide ligase (ADP) EC. 6.4.I.2) was assayed using a method based on that described by Matsuhashi (1969) but omitting EDTA and including $2 \mathrm{mM}^{-\mathrm{Mn}^{2+}}$. The final volume was $\mathrm{I} \cdot 0 \mathrm{ml}$, the reaction being started by adding $0.1 \mathrm{ml}$ of cell-free extract. The enzyme preparation and the assay mixture were held at $30^{\circ} \mathrm{C}$ for Io min before mixing. $\left[2{ }^{14} \mathrm{C}\right]$ Acetic acid $(2 \mu \mathrm{mol} ; \mathrm{I} \mu \mathrm{Ci})$ with $\mathrm{CoA}$ were sometimes replaced in the assay by $\left[2{ }^{14} \mathrm{C}\right]$ acetyl-CoA (I $\mu \mathrm{mol}$; I $\mu \mathrm{Ci}$ ). Effectors of the enzyme were added to the assay mixture before adding the enzyme. The reaction was stopped after $15 \mathrm{~min}$ at $30^{\circ} \mathrm{C}$ by adding $0.5 \mathrm{ml} 5 \mathrm{M}-\mathrm{KOH}$, containing I $\mu$ mol hexadecanoic acid to act as carrier. Hexadecanoic acid was recovered by solvent extraction and, after appropriate washing, its 
radioactivity was counted by liquid scintillation. The activity of the enzyme in all preparations used was linear with respect to time of incubation for up to $20 \mathrm{~min}$, and with respect to protein concentration was linear up to $\mathrm{I} \cdot 5 \mathrm{mg}$ protein $/ \mathrm{ml}$ of assay mixture in the presence of 75 mM-citrate.

Fatty acid synthetase was assayed according to Lynen (1969), except that bovine serum albumin was omitted. Fatty acids formed from $\left[2-{ }^{14} \mathrm{C}\right]$ malonyl-CoA were assayed by the same method used in determination of acetyl-CoA carboxylase activity.

Preparation of CoA-esters. $\left[2-{ }^{14} \mathrm{C}\right]$ Acetyl-CoA was prepared from the labelled anhydride according to Simon \& Shemin (I953); $\left[2{ }^{14} \mathrm{C}\right]$ malonyl-CoA was prepared from the free acid according to Trams \& Brady (I960) and long-chain acyl-CoA esters were prepared from the corresponding acyl chlorides by the method of Seubert (I960).

Chemicals used. All materials used in enzyme assays were obtained from Sigma Chemical Co. Ltd, London. Radiochemicals were obtained from the Radiochemical Centre, Amersham, Buckinghamshire. $n$-Decane, $n$-hexadecane and $n$-decanol, each at $99 \%$ purity, were from Koch-Light Laboratories Ltd, Colnbrook, Buckinghamshire. The fraction of $n$-alkanes used for cultivation of the yeast contained $2.3 \% \mathrm{C}_{13}, 55 \cdot 7 \% \mathrm{C}_{14}, 35.3 \% \mathrm{C}_{15}$ and $6.6 \% \mathrm{C}_{16}$ $n$-alkanes and was a gift from Texaco Ltd, London.

\section{RESULTS}

\section{Glucose-grown Candida $\mathrm{I} 07$}

Activation and inhibition of fatty acid synthetase complex. The fatty acid synthetase complex, as isolated from pigeon liver, is activated maximally by fructose 1,6 -diphosphate but only poorly by inorganic phosphate (Wakil et al. 1966). The enzyme from Candida 107, however, showed only poor stimulation of activity by fructose I,6-diphosphate alone and appeared to have an absolute requirement for inorganic phosphate for maximum stimulation (Fig. I). Subsequent assays of the fatty acid synthetase complex were therefore always performed in IOO mM-phosphate buffer, without fructose I,6-diphosphate. Fructose I,6diphosphate may have exerted its slight activation in tris buffer through hydrolysis by an appropriate phosphatase, to yield some inorganic phosphate in these assays.

In Saccharomyces cerevisiae, the fatty acid synthetase complex is inhibited by long-chain acyl-CoA esters (Lust \& Lynen, 1968). In Candida 107, however, low concentrations of hexadecyl-CoA appeared to stimulate activity of fatty acid synthetase complex, perhaps by helping to disperse the protein of the extract more thoroughly, and only when the ester exceeded $100 \mu \mathrm{M}$ was inhibition observed (Fig. 2).

Activation and inhibition of acetyl-CoA carboxylase. The assay of acetyl-CoA carboxylase relies upon excess activity of the fatty acid synthetase complex within the crude extract; this was always present when assaying acetyl-CoA carboxylase in $100 \mathrm{mM}$-phosphate buffer (see Table 3) and therefore these assays were valid. When studying hexadecyl-CoA as an effector on acetyl-CoA carboxylase activity (see below), care was again taken to ensure that the activity of the fatty acid synthetase, though inhibited, was still above that of the carboxylase.

Citrate was found markedly to stimulate activity of acetyl-CoA carboxylase (Fig. 3). The response to stimulation by citrate, however, depended upon the state of Candida Io7 from which the extract was obtained. If exponentially growing Candida 107 was used, a plot of enzyme activity against citrate concentration was sigmoidal (Fig. 3), but if the extract was prepared from yeast which had been starved for $24 \mathrm{~h}$, the curve became hyperbolic though total activity was now decreased by about $65 \%$. One explanation for this is that during the starvation period enzyme inhibitors, as well as the enzyme itself, were degraded within the 


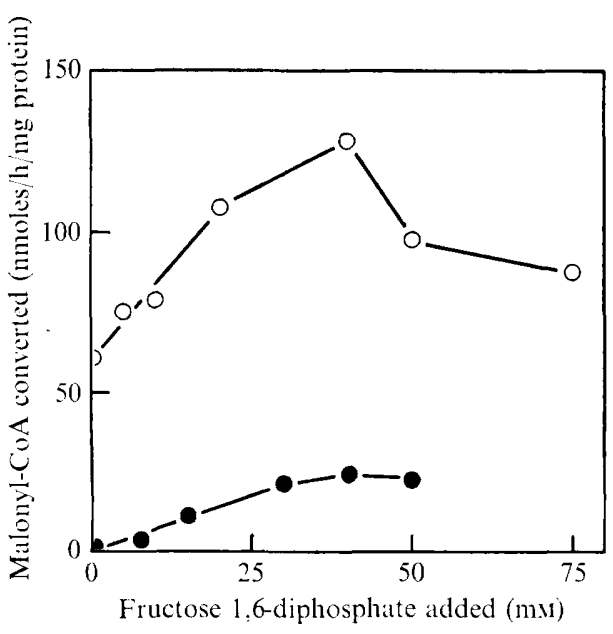

Fig. I

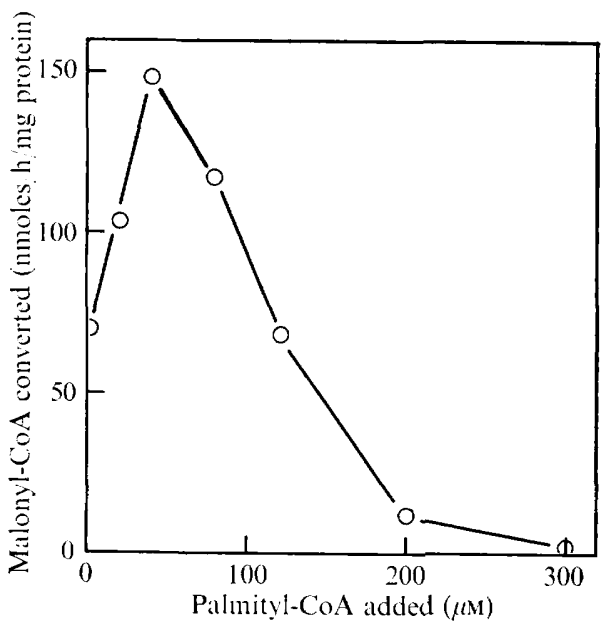

Fig. 2

Fig. I. Activation of the fatty acid synthetase complex in extracts from glucose-grown Candida 107, starved for $24 \mathrm{~h}$ before harvesting, by fructose 1,6-diphosphate in the presence of either $0 . \mathrm{I}$ M-phosphate buffer ( $\mathrm{pH} 7.0)(\mathrm{O})$, or $0.1 \mathrm{M}$-tris buffer $(\mathrm{O})$.

Fig. 2. Effect of palmityl-CoA on the fatty acid synthetase complex in extracts from glucose-grown Candida 107 starved for $24 \mathrm{~h}$ before harvesting.

yeast. Alternative explanations are however possible, as crude extract preparations were used in this work.

The effect of $n$-alkanes and their oxidation products (alcohol, free acid and acyl-CoA) on acetyl-CoA carboxylase activity was subsequently examined both in the presence and absence of citrate (Table I). $n$-Alkanes and hexadecanoic acid, up to $300 \mu \mathrm{M}$, had no effect. $n$-Decanol, however, stimulated activity both in the presence and absence of citrate, possibly by a similar mechanism to that previously noted for the stimulation of fatty acid synthetase activity by low concentrations of hexadecyl-CoA (see Fig. 2). Although $300 \mu \mathrm{M}$-hexadecylCoA was always strongly inhibitory, hexadecyl-CoA at 100 and $200 \mu \mathrm{M}$, and decanoic acid at $300 \mu \mathrm{M}$, strongly inhibited acetyl-CoA carboxylase activity only when assayed in the presence of citrate. The nature of the inhibitions brought about by these latter substances was therefore examined further.

Hexadecyl-CoA, at Ioo and $200 \mu \mathrm{M}$, did not inhibit the basal activity of the enzyme but prevented the activation of the enzyme by citrate. There was a slow, linear increase in enzyme activity with increasing citrate concentration until, with the lower concentration of hexadecyl$\mathrm{CoA}$, a critical point was reached after which the increase in activity with increasing citrate concentration became extremely rapid (Fig. 4a). Presumably a similar pattern would have been observed with the higher concentration of hexadecyl-CoA if the concentration of citrate had been taken beyond I00 mM.

Decanoic acid produced a different pattern of inhibition to that brought about by hexadecyl$\mathrm{CoA}$, in that low concentrations of citrate continued to stimulate enzyme activity without any effect by added decanoic acid (Fig. $4 b$ ). Inhibition was only seen when activation by citrate had doubled the initial activity of the enzyme. Full activation was still attainable nevertheless by continuing to increase the citrate concentration. Dodecanoic acid had no effect on the enzyme activity at any concentration of citrate and is therefore, at $100 \mu \mathrm{M}$, equivalent in this respect to $300 \mu \mathrm{M}$-hexadecanoic acid. 


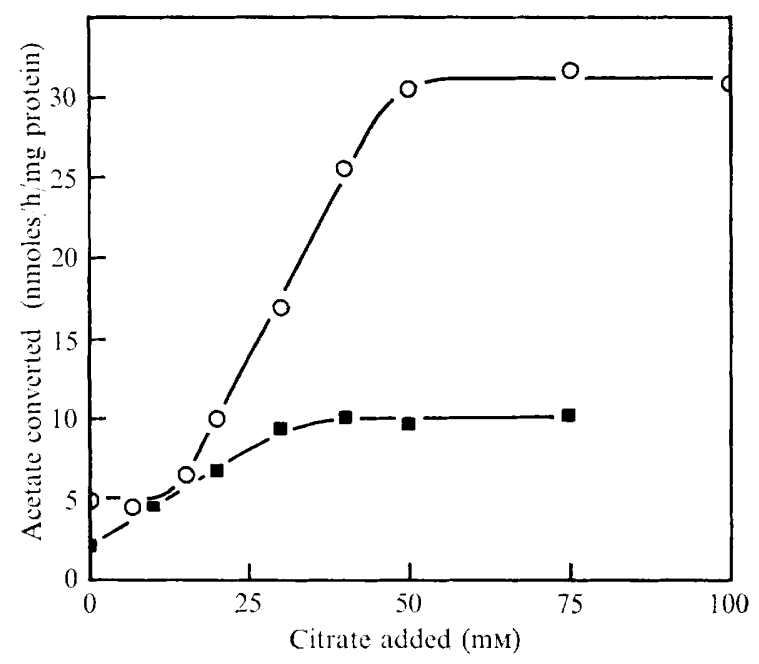

Fig. 3. Citrate activation of acetyl-CoA carboxylase in extracts from glucose-grown Candida ro7, (O) harvested at the end of exponential growth, or ( $\square$ ) starved for $24 \mathrm{~h}$ after the end of growth.

Table I. Action of possible effectors on activity of acetyl-CoA carboxylase from glucose-grown Candida 107 harvested at the end of exponential growth

\begin{tabular}{|c|c|c|c|c|c|}
\hline \multirow[b]{2}{*}{ Effector* } & \multirow[b]{2}{*}{ Concn. $(\mu \mathrm{M})$} & \multicolumn{4}{|c|}{$\begin{array}{c}\text { Enzymatic activity } \\
\text { (nmol acetate converted } / \mathrm{h} / \mathrm{mg} \text { protein) }\end{array}$} \\
\hline & & $\begin{array}{l}\text { Without } \\
\text { citrate }\end{array}$ & $\begin{array}{c}\text { Relative } \\
\text { activity (\%) }\end{array}$ & $\begin{array}{l}\text { With citrate } \\
\quad(75 \mathrm{mM})\end{array}$ & $\begin{array}{c}\text { Relative } \\
\text { activity (\%) }\end{array}$ \\
\hline None & - & $5 \cdot 2$ & 100 & $31 \cdot 6$ & 100 \\
\hline \multirow{3}{*}{ Hexadecyl-CoA } & 100 & $5 \cdot 6$ & 108 & $3 I \cdot 6$ & 100 \\
\hline & 200 & $5 \cdot 6$ & 108 & $9 \cdot 2$ & 29 \\
\hline & 300 & 0 & 0 & $1 \cdot 8$ & 6 \\
\hline Hexadecanoic acid & 300 & $5 \cdot 8$ & II 2 & $30 \cdot 4$ & 96 \\
\hline Decanoic acid & 300 & $6 \cdot 2$ & II9 & $17 \cdot 0$ & 54 \\
\hline Decanol & 500 & $7 \cdot 2$ & 138 & $54 \cdot 6$ & I 71 \\
\hline$n$-Alkanes $\dagger$ & 300 & $4 \cdot 5$ & 87 & $32 \cdot 0$ & IOI \\
\hline
\end{tabular}

Inhibition of enzyme activity by long-chain acyl-CoA esters was not confined to hexadecylCoA but was dependent upon the chain length of the acyl moiety (Table 2). This is similar to previous observations made with acetyl-CoA carboxylase isolated from rat liver (Bortz \& Lynen, I963). Dodecyl- and tetradecyl-derivatives slightly stimulated enzyme activity at concentrations that were inhibitory when the hexadecyl- and octadecyl-esters were used (Table 2).

\section{Alkane-grown Candida I07}

Repression of fatty acid biosynthesis. Extracts of Candida 107 grown on $n$-alkanes, or adapted to alkane utilization after growth on glucose, had activities of the fatty acid synthetase complex which were repressed to about half the activity observed in glucose-grown Candida 107. Even more striking was that the activity of the acetyl-CoA carboxylase had become almost completely repressed by exposure to alkanes (Table 3 ). The failure to detect 

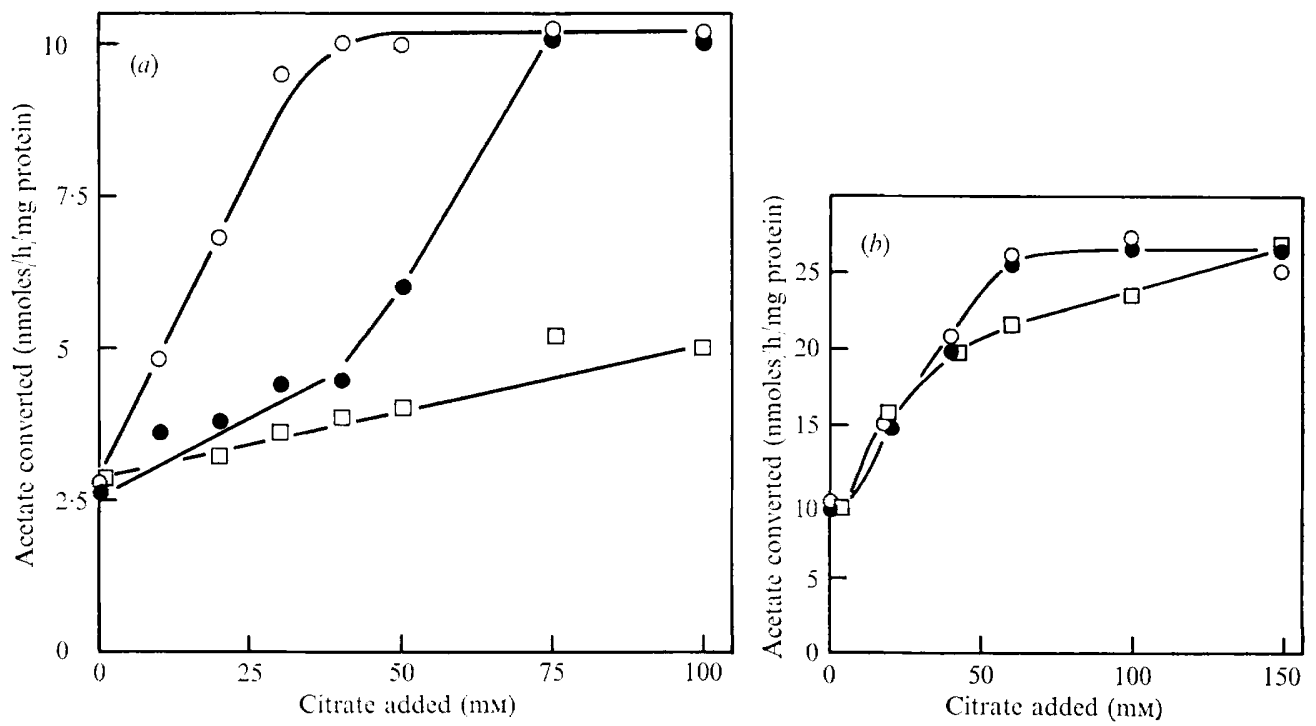

Fig. 4. Effect of long-chain acyl compounds on the activation by citrate of acetyl-CoA carboxylase in extracts from glucose-grown Candida I07. (a) Effect of hexadecyl-CoA at I00 $\mu_{\mathrm{M}}(\mathrm{O})$, and $200 \mu \mathrm{M}(\square)$; control (no addition), (O). (Yeast starved before harvesting.) $(b)$ Effect of dodecanoic acid at $100 \mu_{\mathrm{M}}(\odot)$ and decanoic acid at $100 \mu_{\mathrm{M}}(\square)$; control (no addition), ( $\left.\bigcirc\right)$. (Yeast harvested at end of exponential growth.)

Table 2. Effect of long-chain acyl-CoA esters on activity of acetyl-CoA carboxylase from glucose-grown Candida 107 harvested at the end of exponential growth

$\begin{array}{lccc}\begin{array}{c}\text { Ecyl group of } \\ \text { acyl-CoA }\end{array} & \begin{array}{c}\text { Enzymatic activity } \\ \text { (nmol acetate } \\ \text { converted/ } \\ \text { h/mg protein) }\end{array} & \begin{array}{c}\text { Relative } \\ \text { activity } \\ (\%)\end{array} \\ \text { None } & - & 28 \cdot 4 & 100 \\ \text { Dodecyl- } & 100 & 34 \cdot 4 & \text { I2I } \\ \text { Tetradecyl- } & 200 & 31 \cdot 8 & \text { II2 } \\ \text { Hexadecyl- } & 100 & 30 \cdot 2 & \text { I07 } \\ & 200 & 28 \cdot 2 & 99 \\ \text { Octadecyl- } & 100 & 28 \cdot 6 & \text { 10I } \\ & 200 & 9 \cdot 6 & 34 \\ & 100 & 16 \cdot 0 & 56 \\ & 200 & 7 \cdot 2 & 25\end{array}$

significant activity of this latter enzyme was not due to inability of these extracts to synthesize acetyl-CoA, for when acetyl-CoA was used in the assay system, no increase in the activity of the carboxylase was recorded (Table 3). The slight residual activity was independent of the presence of citrate (up to $200 \mathrm{~mm}$ was used) and unaffected by the addition of decanol or the absence of bicarbonate, though it did still show some slight decrease in activity when phosphate was omitted from the assay. These observations indicate that the apparent residual activity of this enzyme as measured is probably spurious, and due mainly to side-reactions involving formation of ether-soluble material, other than fatty acids, from acetate in the assay system. The actual repressed level of acetyl-CoA carboxylase, therefore, is probably much lower than those recorded in Table 3. 
Table 3. Activities of acetyl-CoA carboxylase and the fatty acid synthetase complex of Candida 107 grown on glucose or alkanes

\begin{tabular}{|c|c|c|c|c|}
\hline $\begin{array}{l}\text { Growth } \\
\text { substrate }\end{array}$ & Growth conditions & $\begin{array}{l}\text { acetyl-CoA } \\
\text { carboxylase }\end{array}$ & $\begin{array}{l}\text { Acetyl-CoA } \\
\text { carboxylase* }\end{array}$ & $\begin{array}{l}\text { synthetase } \\
\text { complex }\end{array}$ \\
\hline Glucose & Batch: harvested after $24 \mathrm{~h}$ & $\begin{array}{l}\text { Acetate } \\
\text { Acetyl-CoA }\end{array}$ & $\begin{array}{l}3 I \cdot 6 \\
2 I \cdot 6\end{array}$ & $\begin{array}{l}70 \cdot 0 \\
\text { N.D. }\end{array}$ \\
\hline Glucose & $\begin{array}{l}\text { Batch: starved } 24 \text { h after } \\
\text { glucose exhaustion }\end{array}$ & Acetate & $10 \cdot 2$ & $60 \cdot 5$ \\
\hline $\mathrm{C}_{13}-\mathrm{C}_{16}$ alkanes & Continuous culture & $\begin{array}{l}\text { Acetate } \\
\text { Acetyl-CoA }\end{array}$ & $\begin{array}{l}0.7 \\
0.4\end{array}$ & $\begin{array}{l}37 \cdot 2 \\
\text { N.D. }\end{array}$ \\
\hline Glucose & $\begin{array}{l}\text { Batch: adapted to hexadecane } \\
\text { for } 24 \mathrm{~h} \text { after glucose exhaustion }\end{array}$ & Acetate & $I \cdot 0$ & N.D. \\
\hline Glucose & $\begin{array}{l}\text { Batch: adapted to decane for } \\
24 \mathrm{~h} \text { after glucose exhaustion }\end{array}$ & Acetate & 0.6 & N.D. \\
\hline
\end{tabular}

The absence of acetyl-CoA carboxylase activity in Candida 107 grown on alkanes could be due to an inhibitor within the extract. This was tested by mixing an extract from alkanegrown Candida 107 with an extract prepared from glucose-grown Candida 107 (Fig. 5). Although an inhibitor, or inhibitors, were indeed indicated to be present within the extract from alkane-grown Candida 107, these were not the cause of the lack of acetyl-CoA carboxylase activity, since in the mixed extract addition of $75 \mathrm{~mm}$-citrate completely restored the activity to the expected value. There was no indication that any activity within this mixture was derived from the extract from alkane-grown Candida 107. The relief of inhibition by citrate followed the same pattern as that for the relief of acetyl-CoA carboxylase inhibited with hexadecyl-CoA (see Fig. 4a).

\section{DISCUSSION}

De novo fatty acid biosynthesis is absent when Candida 107 is grown on $n$-alkanes of any chain length. The enzyme which is principally regulated is acetyl-CoA carboxylase which is apparently totally repressed. Synthesis of this enzyme is clearly not co-ordinate with that of the fatty acid synthetase complex, whose individual genes in yeast are already known to be co-ordinately expressed (Schweizer, Kühn \& Castorph, I97r), as only partial repression of the complex was observed even after several days' continuous cultivation of the yeast on $n$-alkanes. The absence of carboxylase activity leads us to conclude that all fatty acids within the $n$-alkane-grown yeast must be derived from the $n$-alkanes themselves. This still applies when a short-chain alkane such as $n$-decane is used as sole carbon source and, with such substrates, elongation of the derived fatty acid must occur. The lipid of Candida I07 growing on an alkane with an odd number of carbon atoms, however, still contains a high proportion of even-chain-length acids (Thorpe \& Ratledge, I972) but there is no information regarding the mechanism by which these acids are formed. Some $\alpha$-oxidation, as well as $\mathrm{C}_{2}$-unit elongation, may be expected to occur. The absence of de novo fatty acid synthesis in alkane- 


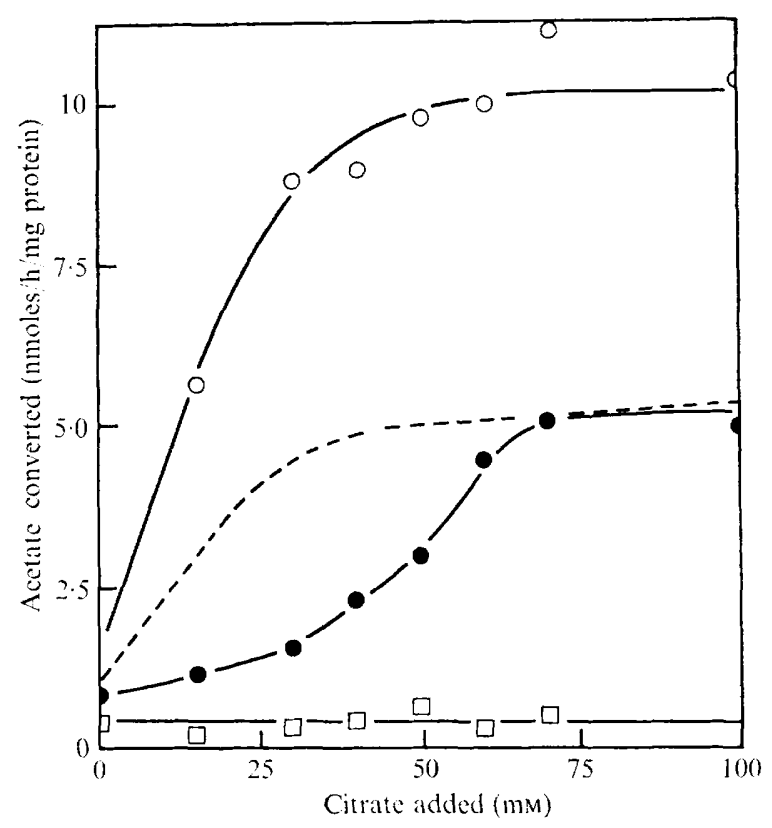

Fig. 5. Establishment of an inhibitor for acetyl-CoA carboxylase in extracts from alkane-grown Candida 107 which can be overcome by citrate. Activity of enzyme from glucose-grown Candida 107 starved before harvesting $(O)$ and from alkane-grown Candida $107(\square)$. Activity of $1:$ I mixture of both extracts: observed result (O); expected result if no interaction (----). (N.B. Activity of acetyl-CoA carboxylase in alkane-grown Candida 107 is still minimal even in the presence of high concentration of citrate; see text.)

grown Candida 107 suggests that this yeast may be useful for studying fatty acid modifications, particularly the poorly characterized $\mathrm{C}_{2}$-unit elongation mechanism which occurs in many systems.

Acetyl-CoA carboxylase is not only a repressible enzyme but, being sensitive to allosteric effectors, is involved in the short-term, or fine, control of fatty acid biosynthesis. In this respect, the enzyme from Candida 107 appears similar to that obtained from other sources which are activated, with aggregation of monomer sub-units (Moss \& Lane, 1972), by a number of metabolic intermediates, in particular, citrate (Lane, Moss, Ryder \& Stoll, I97I). This activation can be competitively inhibited by long-chain fatty acyl-CoA esters (Numa, Ringlemann \& Lynen, 1965; Goodridge, 1972) but it is still not clearly established that these effects constitute a control mechanism in vivo. The evidence relating to short-term control of acetyl-CoA carboxylase has been reviewed at length by Vagelos (I97I), and doubts regarding the action of citrate and long-chain acyl-CoA esters in vivo apply equally to the results we have now obtained with Candida 107. More recently, however, Guynn et al. (1972), after an examination of possible effectors of fatty acid biosynthesis in freezeclamped liver, concluded that only the concentration of long-chain fatty acyl-CoA ester varied in a manner which was consistent with that of a controlling metabolite.

The process of alkane oxidation clearly extensively modifies intermediary metabolism within Candida I07. Alkanes have already been shown to inhibit simultaneously both glucose transport and its catabolism (Gill \& Ratledge, I973 $a$ ), and these events were conjectured to be instigated by products of alkane oxidation acting as direct feedback-inhibitors of certain 
key enzymes. Our results now indicate that of the intermediates of alkane oxidation, only long-chain fatty acyl-CoA esters, produced either directly from a long-chain alkane $\left(\mathrm{C}_{16}\right.$ to $\mathrm{C}_{18}$ in length) or by elongation of a shorter acyl-CoA ester, could cause the inhibition of fatty acid biosynthesis. Such inhibition would lead to the accumulation of acetyl-CoA, and the consequences of this are likely to be profound as far as further effects on intermediary metabolism are concerned. Direct, or indirect, inhibition of glycolysis, glucose transport and other key processes can be anticipated to occur in keeping with the experimental observations. Since we can produce in Candida 107 either complete inhibition of glucose catabolism or the simultaneous utilization of both alkane and glucose, depending upon the state of the yeast and the chain length of the alkane substrate, this organism may be a useful model for studying the inter-relationships between fatty acid and carbohydrate metabolism including the exact nature of control of de novo fatty acid biosynthesis.

We gratefully thank Croda Universal Ltd, for a research scholarship in support of C.O.G.

\section{REFERENCES}

BeLL, G. H. (I97I). The action of monocarboxylic acids on Candida tropicalis growing on hydrocarbon substrates. Antonie van Leeuwenhoek 37, 385-400.

BeLL, G. H. (I973). The metabolism of long chain fatty acids and alcohols by Candida tropicalis and Saccharomyces carlsbergensis. Antonie van Leeuwenhoek 39, I37-149.

Birnbaum, J. (1970). Repression of acetyl coenzyme A carboxylase by unsaturated fatty acid: relationship to coenzyme repression. Journal of Bacteriology 104, 17I-176.

BorTZ, W. M. \& LyNEN, F. (1963). The inhibition of acetyl coenzyme A carboxylase by long-chain acyl coenzyme A derivatives. Biochemische Zeitschrift 337, 505-509.

Burton, D. N., Collins, J. M., Kennan, A. L. \& Porter, J. W. (I969). The effects of nutritional and hormonal factors on the fatty acid synthetase level of rat liver. Journal of Biological Chemistry 244, $4510-45 \mathrm{I} 6$.

Butterworth, P. H. W., Guchhat, R. B., Baum, H., Olson, E. B., Margolis, S. A. \& Porter, J. W. (1966). Relationship between nutritional status and fatty acid synthesis by microsomal and soluble enzymes of pigeon liver. Archives of Biochemistry and Biophysics 116, 453-457.

Chenouda, M. S. \& JWANNY, E. W. (1972). Utilization of hydrocarbons by micio-organisms; lipids and phospholipids of Candida lipolytica grown on hexadecane and on glucose media. Journal of General and Applied Microbiology 18, 18I-I88.

Dahlen, J. V., Kennan, A. L. \& Porter, J. W. (1968). Effect of alloxan and portacaval shunt on the synthesis of fatty acids and sterols by rat liver. Archives of Biochemistry and Biophysics 124, 5I-57.

DAvis, J. B. (1964). Microbial incorporation of fatty acids derived from $n$-alkanes into glycelides and waxes. Applied Microbiology 12, 210-214.

Dorsey, J. A. \& PoRTER, J. W. (1968). The effect of palmityl coenzyme A on pigeon liver fatty acid synthetase. Journal of Biological Chemistry 243, 3512-3516.

Gill, C. O. \& RATLEDGE, C. (I972). Toxicity of $n$-alkanes, $n$-alk-I-enes, $n$-alkan-I-ols and $n$-alkyl-Ibromides towards yeasts. Journal of General Microbiology 72, I65-172.

GILL, C. O.\& RATLEDGE, C. (1973a). Inhibition of glucose assimilation and transport by $n$-decane and other $n$-alkanes in Candida 107. Journal of General Microbiology 75, II-22.

Gill, C. O. \& RATLEDGE, C. (1973b). Control of fatty acid biosynthesis in an alkane utilizing yeast. Journal of General Microbiology 75, xvi-xvii.

GoODRIDGE, A. G. (1972). Regulation of the activity of acetyl coenzyme A carboxylase by palmityl coenzyme A and citrate. Journal of Biological Chemistry 247, 6946-6952.

Guynn, R. W., Veloso, D. \& Veech, R. L. (1972). The concentration of malonyl CoA and the control of fatty acid synthesis in vivo. Journal of Biological Chemistry 247, 7325-733I.

Henderson, T. O. \& MCNeILL, J. J. (1966). The control of fatty acid synthesis in Lactobacillus plantarum. Biochemical and Biophysical Research Communications 25, 662-669.

Henderson, T. O. \& MCNeiLl, J. J. (1967). Further studies on the control of fatty acid synthesis in Lactobacillus plantarum. Bacteriology Proceedings, 134. 
HoRneI, S., KöHLER, M. \& WEIDE, H. (I972). Das Fettsäurespektrum eines Candida-Stammes nach Kultur auf $n$-Alkenen. Zeitschrift für allgemeine Mikrobiologie II, 19-27.

HUG, H. \& FIECHTER, A. (1973). Assimilation of hydrocarbons by Candida tropicalis. II. Fatty acid profiles from cells grown on substrates of different chain length. Archiv für Mikrobiologie 88, 87-96. 'ं

Hunter, K. \& Rose, A. H. (197I). Yeast lipids and membranes. The Yeasts, vol. 2, pp. 2 I I-270. Edited by A. H. Rose and J. S. Harrison. New York and London: Academic Press.

LANE, M. D., Moss, J., RYder, E. \& STOLL, E. (197I). Activation of acetyl-CoA carboxylase by tricarboxylic acids. In Advances in Enzyme Regulation, vol. 9, pp. 237-25I. Edited by G. Weber. Oxford: Pergamon Press.

Lowry, O. H., Rosebrough, N. J., Farr, A. L. \& Randall, R. J. (I95I). Protein measurement with the Folin phenol reagent. Journal of Biological Chemistry I93, 265-275.

Lust, G. \& Lynen, F. (I968). The inhibition of the fatty acid synthetase multienzyme complex of yeast by long-chain acyl-coenzyme A compounds. European Journal of Biochemistry 7, 68-72.

LYNEN, F. (1969). Yeast fatty acid synthetase. In Methods in Enzymology, vol. 14, pp. I7-32. Edited by J. M. Lowenstein. New York and London: Academic Press.

Majerus, P. W. \& Kilburn, E. (1969). Acetyl-CoA carboxylase. The roles of synthesis and degradation in regulation of enzyme levels in rat liver. Journal of Biological Chemistry 244, 6254-6262.

Marquis, N. R., Francesconi, R. P. \& Villee, C. A. (I968). A role for carnitine and long-chain acylcarnitine in the regulation of lipogenesis. In Advances in Enzyme Regulation, vol. 6, pp. 3I-56. Edited by G. Weber. Oxford: Pergamon Press.

Matsuhashi, M. (1969). Acetyl-coenzyme A carboxylase from yeast. In Methods in Enzymology, vol. I4, pp. 3-8. Edited by M. J. Lowenstein. New York and London: Academic Press.

Mizuno, M., Shimojima, Y., Iguchi, T., Takeda, I. \& Senoh, S. (I966). Fatty acid composition of hydrocarbon-assimilating yeasts. Agricultural and Biological Chemistry 30, 506-510.

Moss, J. \& LANe, M. D. (1972). Acetyl-coenzyme A carboxylase. III. Further studies on the relation of catalytic activity to polymeric state. Journal of Biological Chemistry 247, 4944-495 r.

NumA, S., Bortz, W. M. \& Lynen, F. (1965). Regulation of fatty acid synthesis at the acetyl-coenzyme A carboxylation step. In Advances in Enzyme Regulation, vol. 3, pp. 407-423. Edited by G. Weber. Oxford: Pergamon Press.

Numa, S., Ringlemann, E. \& Lynen, F. (1965). Zur Hemmung der Acetyl Coenzyme A Carboxylase durch Fettsäure-CoA-Verbindungen. Biochemische Zeitschrift 343, 243-257.

RAsmussen, R. K. \& KLEIN, H. P. (1968). Activation of fatty acid synthesis in cell-free extracts of Saccharomyces cerevisiae. Journal of Bacteriology 95, I 57-161.

RATLEDGe, C. (1968). Production of fatty acids and lipids by Candida sp. growing on a fraction of $n$-alkanes predominating in tridecane. Biotechnology and Bioengineering $10,5 \mathrm{I} \mathrm{I}-533$.

RATLEDGE, C. (1970). Microbial conversions of $n$-alkanes to obtain economical microbial fats and fatty acids. Chemistry and Industry, pp. 843-854.

Schwetzer, E., KuHN, L. \& CASTORPH, H. (I97I). A new gene cluster in yeast: the fatty acid synthetase system. Hoppe-Seyler's Zeitschrift für physiologische Chemie 352, 377-384.

Seubert, W. (I 960). S-Palmityl coenzyme A. In Biochemical Preparations, vol. 7, pp. 80-83. Edited by H. A. Lardy. New York and London: John Wiley \& Sons Inc.

Simon, E. J. \& Shemin, D. (1953). Synthesis of acetyl-CoA. Journal of the American Chemical Society 75 , 2520 .

SUMPER, M. \& Lynen, F. (I972). The multienzyme system of fatty acid biosynthesis. Hoppe-Seyler's Zeitschrift für physiologische Chemie 353, 502.

Suomalainen, H. \& KerÄNEn, A. J. A. (1968). The fatty acid composition of baker's and brewer's yeast. Chemistry and Physics of Lipids 2, 296-3 I5.

Thorpe, R. F. \& RATLedGe, C. (1972). Fatty acid distribution in triglycerides of yeasts grown on glucose or n-alkanes. Journal of General Microbiology 72, $15 \mathrm{I}-\mathrm{I} 63$.

Trust, T. J. \& Millis, N. F. (1970). The isolation and characterization of alkane-oxidizing organisms and the effect of growth substrate on isocitric lyase. Journal of General Microbiology 6r, 245-254.

Trams, E. G. \& Brady. R. O. (1960). The synthesis of malonyl $-{ }^{14} \mathrm{C}$ CoA. Journal of the American Chemical Society 82, 2972-2973.

TubBs, P. K. \& Garland, P. B. (1964). Variation in tissue contents of CoA thioesters and possible metabolic implications. Biochemical Journal 93, 550-557.

Vagelos, P. R. (197I). Regulation of fatty acid biosynthesis. In Current Topics in Cellular Regulation, vol. 4, pp. I I9-166. Edited by B. L. Horecker and E. R. Stadtman. New York and London: Academic Press. 
Wakil, S. J., Goldman, J. K., Williamson, I. P. \& Toomey, R. E. (Ig66). Stimulation of fatty acid biosynthesis by phosphorylated sugars. Proceedings of the National Academy of Sciences of the United States of America 55, 880-887.

WEEKS, G. \& WAKIL, S. J. (1970). Studies on the control of fatty acid metabolism. II. The inhibition of fatty acid synthesis in Lactobacillus plantarum by exogenous fatty acid. Journal of Biological Chemistry $\mathbf{2 4 5}$, I9I3-I92I.

White, D. \& KLEIN, H. P. (1965). Factors affecting fatty acid synthesis in cell-free preparations from Saccharomyces cerevisiae. Biochemical and Biophysical Research Communications 20, 78-84.

White, D. \& KLeIN, H. P. (I966). Effects of $\alpha$-glycerophosphate and of palmityl coenzyme A on lipid synthesis in yeast extracts. Journal of Bacteriology 91, I 2 I 8-I 223. 